Jurnal Cahaya Mandalika, Vol. 3, No. 1, 2022 ,e- ISSN: 2721-4796

Available online at: http://ojs.cahayamandalika.com/index.php/JCM

Copyright (c) 2021 Publisher: Institut Penelitian \& Pengembangan Mandalika Indonesia

\title{
FAKTOR-FAKTOR YANG MEMPENGARUHI PENYERAPAN TENAGA KERJA PADA UMKM INDUSTRI ROTI DI KOTA PAYAKUMBUH
}

\author{
Mega Amelia Putri ${ }^{1^{*}}$, John Nefri ${ }^{2}$, Retno Setiawan $^{3}$ \\ ${ }^{1,2,3}$ Program Studi Pengelolaan Agribisnis, Jurusan Budidaya Tanaman Pangan, \\ Politeknik Pertanian Negeri Payakumbuh \\ E-mail Corresponden Author : "lia.politani@gmail.com
}

\begin{abstract}
Abstrak: Penelitian ini bertujuan untuk mengetahui pengaruh upah, modal, nilai penjualan, tingkat produktifitas dan tingkat pendidikan tenaga kerja terhadap penyerapan tenaga kerja pada UMKM industri roti di Kota Payakumbuh. Penelitian ini dilakukan terhadap 30 pengusaha pemilik industri roti yang masih aktif dan beroperasi. Data dalam penelitian ini adalah data primer yang diambil dengan menggunakan metode wawancara berpedoman pada kuesioner dan data sekunder diperoleh dengan metode kepustakaan. Metode analisis yang digunakan dalam penelitian ini adalah analisis regresi linier berganda dengan bantuan SPSS 26 for Windows. Hasil penelitian menunjukkan bahwa variabel upah (X1), nilai penjualan (X3) dan tingkat pendidikan tenaga kerja (X5) berpengaruh positif dan signifikan terhadap penyerapan tenaga kerja. Sedangkan variabel modal (X4) dan tingkat produktifitas tenaga kerja (X4) berpengaruh tidak signifikan terhadap penyerapan tenaga kerja pada UMKM industri roti di Kota Payakumbuh.
\end{abstract}

Kata Kunci : Upah, Modal, Pendidikan, Penjualan, Produktivitas, Regresi Linear Berganda

\section{PENDAHULUAN}

Usaha Mikro Kecil dan Menengah (UMKM) memegang peranan yang signifikan dalam pertumbuhan ekonomi suatu negara, bahkan di negara maju sekalipun. UMKM selalu diperbincangkan dan dikaji untuk terus ditingkatkan peranannya. UMKM ketika dianalisis lebih jauh, maka akan terlihat bahwa hampir separuh lebih dari total usaha yang ada di dunia merupakan kontribusi dari Usaha Mikro Kecil dan Menengah (UMKM). UMKM memiliki peranan yang penting yaitu dalam hal penyerapan tenaga kerja (Anggrayini et al., 2020; Handoko, 2016; Hartono, 2021). Perekonomian Indonesia dapat dikategorikan sebagai perekonomian dengan ciri surplus tenaga kerja. Dengan demikian, aspek ketenagakerjaan menjadi isu yang cukup penting bagi perekonomian. Masalah ketenagakerjaan dipengaruhi oleh banyak aspek, di antaranya iklim investasi, regulasi pemerintah, tingkat upah dan pertumbuhan ekonomi. Pertumbuhan ekonomi yang tinggi tidak serta merta mampu menyediakan lapangan pekerjaan. Di lain sisi, transformasi struktural ekonomi yang terjadi sejak tahun 1980-an tidak disertai dengan transformasi tenaga kerja. Arah perekonomian yang cenderung mengarah ke sektor industri tidak disertai dengan penyerapan tenaga kerja pada sektor tersebut. Tenaga kerja justru membengkak di sektor pertanian (Irwan et al., 2019).

Selain itu, ketenagakerjaan merupakan salah satu aspek yang dapat menentukan tingkat kesejahteraan penduduk (Marti'ah, 2020; Rosyid, 2017; Syuhada et al., 2014) Hal ini karena berkaitan erat dengan dimensi sosial dan dimensi ekonomi. Dilihat dari dimensi sosial, pekerjaan berkaitan dengan pengakuan masyarakat terhadap kemampuan individu. Sedangkan dimensi ekonomi menjelaskan kebutuhan manusia akan pekerjaan berkaitan dengan pemenuhan kebutuhan hidup sehari-hari. Bila dilihat dari sudut ekonomi, pembangunan dapat dikatakan berhasil jika dapat memberikan sumber 
penghidupan yang lebih baik bagi masyarakat. Tenaga kerja merupakan bagian dari penduduk yang secara potensial berperan dalam memproduksi barang dan jasa.

Menurut (BPS Sumatera Barat, 2021)Penyerapan tenaga kerja pada sektor-sektor ekonomi kali ini dikelompokkan menjadi 3 kategori utama yaitu: pertanian, industri dan jasa - jasa. Pada tahun 2020, lapangan usaha jasa-jasa, menyerap tenaga kerja terbanyak di Kota Payakumbuh, yaitu sebanyak 69,07 persen, dimana sebesar 36,67 persen diantaranya adalah tenaga laki-laki dan sebesar 32,40 persen adalah tenaga kerja perempuan. Selanjutnya, lapangan usaha Industri mampu menyerap tenaga kerja sebanyak 21,33 persen, dimana 14,12 persen adalah tenaga kerja laki-laki dan 7,21 persen adalah tenaga kerja perempuan. Sisanya lapangan usaha pertanian menyerap tenaga kerja sebanyak 9,60 persen dengan komposisi tenaga kerja laki-laki adalah sebesar 5,81 persen dan sebesar 3,79 persen tenaga kerja perempuan. Hal ini terlihat bahwa sektor industri juga memberikan kontribusi terhadap penyerapan tenaga kerja di Kota Payakumbuh. Salah satu industri yang ada yaitu industri roti.

UMKM industri roti di Kota Payakumbuh termasuk salah satu kegiatan ekonomi yang memiliki fungsi dan peranan yang sangat strategis karena termasuk salah satu usaha industri kecil yang dapat menjadi roda penggerak perekonomian. Khususnya untuk masyarakat di Kota Payakumbuh yang bermata pencaharian sebagai pengusaha roti, memberikan pendapatan bagi masyarakat, dan juga membuka lapangan kerja baru bagi masyarakat sekitarnya. Kesempatan kerja menjadikan hal penting yang dapat menjadi wadah untuk mengembangkan potensi masyarakat. Tenaga kerja yang semangkin bertambah maka akan meningkatkan produksi roti tersebut, faktor tenaga kerja menjadikan salah satu peranan penting dalam kegiatan produksi, apalagi dengan tenaga kerja yang memiliki keterampilan dalam pembuatan roti akan mempercepat produksi roti ataupun hal lainnya.

Beberapa UMKM industri roti di Kota Payakumbuh selama tahun 2017 - 2021 mengalami penurunan produksi. Hal ini disebabkan oleh beberapa faktor antara lain ketersediaan bahan baku, modal, tenaga kerja dan aspek pemasaran (Saputri, 2021). Hal ini sejalan dengan pendapat (Handoko, 2016; Syahrudin, 2017; Syuhada et al., 2014). suatu usaha akan mampu menyerap tenaga kerja apabila mampu menjalankan usahanya dengan baik dan stabil, pengembangan usaha dapat dilakukan apabila perusahan mampu memanfaatkan modal dan penjualan dengan efektif dan efisien. Kondisi ini akan mampu meningkatkan penyerapan tenaga kerja. Namun sebaliknya, apabila perusahaan tidak mampu mengelolaa usahanya dengan baik maka beberapa perusahaan akan gulung tikar dan tidak bisa mempertahankan usahanya tersebut. Dampaknya tentu saja akan mengurangi penyerapan tenaga kerja. Oleh karena itu, penting dilakukan kajian tentang faktor-faktor yang mempengaruhi penyerapan tenaga kerja pada UMKM industri roti di Kota Payakumbuh.

\section{Metode Penelitian}

Lokasi penelitian ditentukan secara purposive di Kota Payakumbuh, dengan memilih lima (2) kecamatan sebagasi sentra industri roti yaitu Kecamatan Payakumbuh Utara dan Payakumbuh Barat. Jumlah populasi yang terdata sebanyak 143 industri, ditentukan 30 industri roti. Hal ini berdasarkan survei lapangan usaha roti yang tetap aktif dan bertahan banyak Penelitian ini menggunakan data primer dan data sekunder. 
Data primer diperoleh secara langsung melalui wawancara menggunakan kuesioner. Data yang dibutuhkan yaitu nama perusahaan dan pemiliknya, jumlah biaya produksi selama sebulan, harga bahan baku, harga jual produk, jumlah produksi, jumlah tenaga kerja, karakteristik tenaga kerja, dan upah tenaga kerja. Data sekunder diperoleh dari dinas industrial Kota Payakumbuh, BPS Kota Payakumbuh, dan Dinas Koperasi Kota Payakumbuh, jurnal, buku, dan internet yang informasinya relevan dengan penelitian.

\section{Metode Analisis}

Penelitian ini menggunakan analisis regresi linear berganda untuk mengetahui pengaruh variabel independen yaitu upah, modal, dan nilai produksi terhadap variabel dependen yaitu penyerapan tenaga kerja yang diolah menggunakan SPSS 26 for Windows. Secara matematis model tersebut dapat dituliskan sebagai berikut:

$$
Y=\beta_{0}+\beta_{1} X_{1}+\beta_{2} X_{2}+\beta_{3} X_{3}+\beta_{4} X_{4}+\beta_{5} X_{5}+\varepsilon
$$

Keterangan :

$$
\begin{array}{ll}
Y & =\text { Penyerapan tenaga kerja } \\
X_{1} & =\text { Upah } \\
X_{2} & =\text { Modal kerja } \\
X_{3} & =\text { Nilai penjualan } \\
X_{4} & =\text { Produktivitas tenaga kerja } \\
X_{5} & =\text { Tingkat pendidikan tenaga kerja } \\
\beta_{0} & =\text { Konstanta } \\
\beta_{1-5} & =\text { Koefisien parsial dari variabel X } \\
\varepsilon & =\text { Error term }
\end{array}
$$

\section{Uji Hipotesis secara Parsial (Uji t)}

Uji t digunakan untuk mengetahui besarnya signifikansi pengaruh variabel bebas terhadap variabel terikat secara individual atau parsial (Samsu, 2017). Jika nilai sig < tingkat kesalahan/eror (alpha) 0,05 maka variabel bebas berpengaruh signifikan terhadap penyerapan tenaga kerja, sedangkan apabila nilai probabilitas $\mathrm{F}$ hitung > tingkat kesalahan 0,05 maka variabel bebas tidak berpengaruh signifikan terhadap penyerapan tenaga kerja.

\section{Uji Hipotesis secara Simultan (Uji F)}

Uji $\mathrm{F}$ digunakan untuk menunjukan apakah keseluruhan variabel bebas berpengaruh secara bersama-sama terhadap variabel terikat (Samsu, 2017). Jika nilai sig $<$ tingkat kesalahan/eror (alpha) 0,05 maka model regresi yang diestimasi layak, sedangkan apabila nilai probabilitas $\mathrm{F}$ hitung > tingkat kesalahan 0,05 maka model regresi yang diestimasi tidak layak.

\section{Koefisien Determinasi (R2)}

Menurut (Nuryadi et al., 2017) besarnya pengaruh variabel bebas terhadap variabel tergantung dapat diketahui dari besarnya koefisien determinasi berganda (R2). Jika R2 
yang diperoleh dari hasil perhitungan mendekati satu, maka dapat dikatakan bahwa sumbangan dari variabel bebas terhadap variasi variabel terikat semakin besar. Sebaliknya jika R2 semakin kecil atau mendekati nol, maka dapat dikatakan bahwa sumbangan dari variabel bebas terhadap variasi nilai variabel terikat semakin kecil. Meskipun demikian penggunaan koefisien determinasi masih memiliki kelemahan yaitu bias terhadap jumlah variabel independen yang dimasukkan di dalam model. Setiap tambahan variabel independen pasti akan meningkatkan nilai R2 tanpa mempedulikan apakah variabel independen tersebut berpegaruh secara signifikan atau tidak terhadap variabel dependen. Adjusted R2 dapat naik maupun turun apabila terdapat penambahan variabel independen. Atas dasar pertimbangan tersebut, dalam menghitung koefisien determinasi penulis tidak menggunakan R2 tetapi Adjusted R2.

\section{Hipotesis Penelitian}

Hipotesis yang diajukan dalam penelitian ini adalah :

1. H10: upah, modal, nilai penjualan, produktivitas tenaga kerja dan tingkat pendidikan tenaga kerja tidak berpengaruh nyata (tidak signifikan) secara bersamasama (simultan) terhadap penyerapan tenaga kerja pada usaha roti di Kota Payakumbuh.

2. H11: upah, modal, nilai penjualan, produktivitas tenaga kerja dan tingkat pendidikan tenaga kerja berpengaruh nyata (signifikan) secara bersama-sama (simultan) terhadap penyerapan tenaga kerja pada usaha roti di Kota Payakumbuh.

3. H20 : upah tidak berpengaruh nyata (tidak signifikan) secara sendiri (parsial) terhadap penyerapan tenaga kerja pada usaha roti di Kota Payakumbuh

4. H21 : upah berpengaruh nyata (signifikan) secara sendiri (parsial) terhadap penyerapan tenaga kerja pada usaha roti di Kota Payakumbuh.

5. H30 : modal tidak berpengaruh nyata (tidak signifikan) secara sendiri (parsial) terhadap penyerapan tenaga kerja pada usaha roti di Kota Payakumbuh

6. H31 : modal berpengaruh nyata (signifikan) secara sendiri (parsial) terhadap penyerapan tenaga kerja pada usaha roti di Kota Payakumbuh.

7. H40 : nilai penjualan tidak berpengaruh nyata (tidak signifikan) secara sendiri (parsial) terhadap penyerapan tenaga kerja pada usaha roti di Kota Payakumbuh.

8. H41 : nilai penjualan berpengaruh nyata (signifikan) secara sendiri (parsial) terhadap penyerapan tenaga kerja pada usaha roti di Kota Payakumbuh.

9. H50 : produktivitas tenaga kerja tidak berpengaruh nyata (tidak signifikan) secara sendiri (parsial) terhadap penyerapan tenaga kerja pada usaha roti di Kota Payakumbuh.

10. H51 : produktivitas tenaga kerja berpengaruh nyata (signifikan) secara sendiri (parsial) terhadap penyerapan tenaga kerja pada usaha roti di Kota Payakumbuh.

11. H60 : tingkat pendidikan tenaga kerja tidak berpengaruh nyata (tidak signifikan) secara sendiri (parsial) terhadap penyerapan tenaga kerja pada usaha roti di Kota Payakumbuh.

12. H61 : tingkat pendidikan tenaga kerja berpengaruh nyata (signifikan) secara sendiri (parsial) terhadap penyerapan tenaga kerja pada usaha roti di Kota Payakumbuh.

\section{Hasil dan Pembahasan}


Penyerapan tenaga kerja terjadi disebabkan karena permintaan tenaga kerja dari pengusaha atau pemilik usaha. Penyerapan tenaga kerja adalah jumlah tenaga kerja yang mampu digunakan secara produktif dalam kurun waktu tertentu biasanya bulan, diukur dari jumlah jam kerja dalam satu bulan.Penyerapan tenaga kerja dipengaruhi oleh dua faktor yaitu faktor eksternal yang berasal dari luar lingkungan perusahaan salah satunya pemerintah dan faktor internal yang berasal dari dalam lingkungan perusahaan itu sendiri. Menurut (Irwan et al., 2019), faktor eksternal yang mempengaruhi penyerapan tenaga kerja yaitu tingkat pertumbuhan ekonomi, tingkat inflasi, penggangguran dan tingkat bunga. Sedangkan faktor internal dipengaruhi oleh tingkat upah, produktivitas tenaga kerja, modal dan pengeluaran non upah. Pada peneliltian ini variabel yang dianalisis pengaruhnya terhadap penyerapan tenaga kerja yaitu dari faktor internal antara lain faktor upah, modal kerja, nilai penjualan, produktivitas tenaga kerja dan tingkat pendidikan. Hasil analisis faktor-faktor yang mempengaruhi penyerapan tenaga kerja pada UMKM Industri Roti di kota Payakumbuh dapat dilihat pada Tabel 1 berikut ini:

Tabel 1.Hasil Analisis Regresi Liniar Berganda

\begin{tabular}{|c|c|c|c|c|c|}
\hline Model & B & $\begin{array}{l}\text { Standar } \\
\text { Eror }\end{array}$ & $\begin{array}{c}\text { Standardized } \\
\text { Coefficients } \\
\text { Beta } \\
\end{array}$ & $\mathbf{t}$ & Sig. \\
\hline Konstanta & 3,406 & 1,115 & & 3,056 & ,005 \\
\hline Upah (X1) & $1,270 \mathrm{E}-7$ &, 000 & ,289 & 2,836 &, $009 *$ \\
\hline Modal Kerja (X2) & $-2,576 \mathrm{E}-8$ &, 000 &,- 093 & $-1,522$ & 141 \\
\hline Nilai Penjualan (X3) & $-6,382 \mathrm{E}-7$ & 000 &,- 157 & $-2,486$ &, $020^{*}$ \\
\hline $\begin{array}{l}\text { Produktivitas Tenaga Kerja } \\
\text { (X4) }\end{array}$ &,- 001 & 001 &,- 082 & $-1,247$ & ,224 \\
\hline $\begin{array}{l}\text { Tingkat Pendidikan } \\
\text { Tenaga Kerja (X5) }\end{array}$ & ,274 &, 032 & ,814 & 8,269 &, $000^{*}$ \\
\hline R-square & ,954 & & & & \\
\hline Adjusted R-square & ,945 & & & & \\
\hline S.E. of the Estimate & ,934 & & & & \\
\hline F - Statistik & 100,497 & & & & \\
\hline Prob (F-statistik) &, 000 & & & & \\
\hline
\end{tabular}

Keterangan : *Signifikan pada taraf nyata 5\%

Tabel 1 menunjukkan bahwa dari kelima variabel indipenden, secara parsial variabel yang signifikan adalah variabel upah (X1), nilai penjualan (X3) dan tingkat pendidikan tenaga kerja (X5). Sedangkan variabel yang tidak signifikan adalah modal kerja (X2) dan tingkat produktivitas tenaga kerja (X4). Hasil koefisen determinasi (Adjusted R-square) yang diperoleh sebesar 0.945. artinya bahwa variabel upah, modal kerja, nilai penjualan, produktivitas tenaga kerja, tingkat pendidikan tenaga kerja mampu menjelaskan sebesar 94,5\% variasi penyerapan tenaga kerja. Sedangkan sisanya, 5,5\% penyerapan tenaga kerja dapat dijelaskan oleh variabel lain yang tidak digunakan dalam penelitian ini.

Hasil analisis juga menunjukkan bahwa nilai F-hitung sebesar 100,497 > F tabel 2,776 dengan Probabilitas (Prob F-Statistic) 0,000 < 0.05. Maka, model regresi dapat 
digunakan untuk memprediksi penyerapan tenaga kerja industri roti di Kota Payakumbuh. Dengan kata lain, variabel upah, modal kerja, nilai penjualan, produktivitas tenaga kerja dan tingkat pendidikan tenaga kerja secara simultan atau bersama-sama berpengaruh signifikan terhadap penyerapan tenaga kerja. Hal ini sejalan dengan pendapat (Nugrahaeni \& Handayani, 2020) yang menyatakan bahwa faktorfaktor yang menentukan suatu perusahaan menggunakan tenaga kerja secara maksimal biasanya adalah perubahan upah, biaya modal dan input lainnya, serta tingkat penjualan perusahaan.

Model persamaan regresi linear berganda ditunjukkan sebagai berikut :

$Y=3,406+0,000000127 X 1-0,0000000258 X 2-0,0000006382 X 3-0,001 X 4+0,274 X 5$

$+\mathrm{e}$

Persamaan dapat dijelaskan sebagai berikut:

a) Koefisien konstanta pada regresi sebesar 3,406. Koefisien konstanta bernilai positif ini menunjukkan bahwa variabel upah (X1), modal kerja (X2), nilai penjualan (X3), produktiftas tenaga kerja (X4) dan tingkat pendidikan (X5) akan memberikan pengaruh positif terhadap penyerapan tenaga kerja sebesar 3,406 atau dengan kata lain dapat diartikan bahwa tingkat penyerapan tenaga kerja sebesar 3,406 dengan asumsi variabel upah (X1), modal kerja (X2), nilai penjualan (X3), produktiftas tenaga kerja (X4) dan tingkat pendidikan tenaga kerja (X5) konstan.

b) Pengaruh variabel upah (X1) terhadap penyerapan tenaga kerja (Y). Koefisien regresi dari variabel upah (X1) sebesar 0,000000127 dan koefisien regresi bernilai positif ini menjelaskan bahwa apabila upah (X1) mengalami peningkatan satu satuan maka penyerapan tenaga kerja (Y) akan mengalami peningkatan sebesar 0,000000127 dengan asumsi variabel lain konstan.

c) Pengaruh variabel modal kerja (X2) terhadap penyerapan tenaga kerja. Koefisien regresi dari variabel modal kerja (X2) sebesar -0,0000000258 dan koefisien regresi bernilai negatif ini menunjukan bahwa apabila modal kerja (X2) meningkat (bertambah) satu satuan maka penyerapan tenaga kerja akan mengalami penurunan sebesar 0,0000000258 dengan asumsi variabel lain konstan.

d) Pengaruh variabel nilai penjualan (X3) terhadap penyerapan tenaga kerja. Koefisien regresi dari variabel nilai penjualan (X3) sebesar -0,0000006382 dan koefisien regresi bernilai negatif ini menunjukkan bahwa apabila nilai penjualan (X3) meningkat (bertambah) satu satuan maka penyerapan tenaga kerja akan mengalami penurunan sebesar 0,0000006382 dengan asumsi variabel lain konstan.

e) Pengaruh variabel tingkat peroduktifitas tenaga kerja (X4) terhadap penyerapan tenaga kerja Koefisien regresi dari variabel produktivitas tenaga kerja (X4) sebesar 0,001 koefisien regresi bernilai negatif ini menunjukkan bahwa apabila produktivitas (X4) meningkat satu satuan maka penyerapan tenaga kerja akan mengalami penurunan sebesar 0,001 dengan asumsu variabel lain konstan.

f) Pengaruh variabel tingkat pendidikan tenaga kerja (X5) terhadap penyerapan tenaga kerja. Koefisien regresi dari variabel tingkat pendidikan tenaga kerja (X5) sebesar 
Jurnal Cahaya Mandalika, Vol. 3, No. 1, 2022 ,e- ISSN: 2721-4796

Available online at: http://ojs.cahayamandalika.com/index.php/JCM

Copyright (C) 2021 Publisher: Institut Penelitian \& Pengembangan Mandalika Indonesia

0,274 dan koefisien regresi bernilai positif ini menjelaskan bahwa apabila tingkat pendidikan tenaga kerja (X5) mengalami peningkatan satu satuan maka penyerapan tenaga kerja (Y) akan mengalami peningkatan sebesar 0,274 dengan asusmsi variabel lain konstan.

\section{Pengaruh Upah Terhadap Penyerapan Tenaga Kerja pada Usaha Roti di Kota Payakumbuh}

Upah yang digunakan dalam penelitian ini adalah total upah yang dikeluarkan oleh pengusaha sebanyak biaya tenaga kerja yang menggunakan satuan rupiah dengan menghitung total hari kerja selama sebulan. Hasil penelitian menunjukkan upah berpengaruh signifikan secara parsial terhadap penyerapan tenaga kerja. Adanya pengaruh upah terhadap penyerapan tenaga kerja pada usaha roti di Kota Payakumbuh dikarenakan upah yang diberikan kepada tenaga kerja disetiap roti rata-rata sama yaitu Rp1.780.000 untuk perbulan dan Rp62.306 untuk perhari. Perbedaan pemberian selain upah pokok terdapat pada pemberian kepada tenaga kerja yaitu bonus dan fasilitas baju kerja. Tujuan dari pemberian fasilitas pada tenaga kerja adalah untuk menunjang standar keamanan mutu produk yang dihasilkan, kenyamanan karyawan dan juga ini untuk meningkatkan kualitas produk dari usaha tersebut. Sesuai dengan penelitian yang dilakukan oleh (Arnayulis et al., 2020) pada usaha pengolahan ubi kayu di Kota Payakumbuh yang mengatakan bahwa upah berpengaruh signifikan terhadap penyerapan tenaga kerja, dan sejalan dengan penelitian yang dilakukan oleh (Marti'ah, 2020; Rosyid, 2017; Syuhada et al., 2014) mengatakan bahwa upah berpengaruh signifikan terhadap penyerapan tenaga kerja.

Hasil penelitian menunjukkan tenaga kerja paling banyak terserap pada usaha roti yang memberikan upah tinggi, uang lembur dan juga fasilitas selain upah. Terlihat sebesa $43 \%$ usaha roti memiliki jumlah tenaga kerja diatas rata-rata dengan pemberian upah diatas upah rata-rata harian yaitu Rp1.780.000 per bulan dan Rp62.306 per hari. Pada usaha roti ini pula merencanakan adanya penambahan tenaga kerja untuk kegiatan produksi dan pemasaran. Hasil analisis ini sesuai dengan fakta dilapangan bahwa saat peningkatan tenaga kerja maka secara menyeluruh total upah sebuah usaha akan meningkat. Pada beberapa usaha sangat memperhatikan tenaga kerja dengan memberikan upah diatas rata-rata dan memberikan fasilitas seperti baju kerja, serta alat pelindung diri. Hasil penelitian ini didukung dengan penelitian (Handoko, 2016) yang menyatakan variabel upah berpengaruh pada penyerapan tenaga kerja pada UMKM di Kabupaten Bulungan. Hal ini terlihat semakin besar pengeluaran upah semakin banyak tenaga kerja yang bekerja di perusahaan tersebut.

\section{Pengaruh Modal Kerja Terhadap Penyerapan Tenaga Kerja pada Usaha Roti di Kota Payakumbuh}

Modal kerja merupakan modal lancar yang meliputi seluruh uang tunai dan persediaan barang yang digunakan oleh pengusaha dalam memproduksi produk. Modal yang digunakan dalam penelitian ini adalah modal awal meliputi seluruh uang tunai dan persediaan bahan pokok dan bahan penolong yang digunakan oleh pengusaha dalam memproduksi produk roti. Hasil analisis menunjukkan bahwa modal kerja berpengaruh tidak signifikan terhadap penyerapan tenaga kerja pada usaha roti di Kota Payakumbuh. 
Saat ini, umumnya industri roti berproduksi secara sederhana. Mesin yang digunakan oleh usaha roti masih membutuhkan bantuan tenaga kerja dalam pengoperasiannya contohnya mesin ampia roti dan mesin pembagian adonan roti yang mana kedua mesin ini jika tidak ada tenaga kerja yang mengoperasikan maka hasil dari adonan roti ataupun tepung yang sudah diadoni tidak dapat menghasilkan roti.

Usaha roti di Kota Payakumbuh dapat dikatakan usaha padat karya. Menurut (Saputri, 2021) dengan penambahan modal usaha roti akan mampu melaksanakan perluasan usaha sehingga akan memerlukan tenaga kerja tambahan untuk mencukupi kebutuhan usaha. Dengan demikian besarnya modal pada usaha padat karya maka kesempatan kerja yang diciptakan semakin tinggi. Fakta dilapangan modal yang bertambah digunakan oleh pengusaha untuk mengembangkan usahanya sehingga apabila usaha telah berkembang dan permintaan meningkat barulah pengusaha menambah tenaga kerja karena tenaga kerja awal tidak mampu memenuhi jumlah produksi sehingga pengaruh modal terhadap penyerapan tenaga kerja berkaitan dengan pengembangan usaha yang akan dilakukan oleh usaha roti. Berbeda dengan hasil penelitian yang dilakukan oleh (Nugrahaeni \& Handayani, 2020) yang mengatakan bahwa modal berpengaruh signifikan terhadap penyerapan tenaga kerja. Hal ini disebabkan dalam peneltian ini modal yang dimaksud adalah modal kerja atau modal untuk setiap produksi yaitu modal untuk membeli bahan baku dan operasioanl produksi tidak termasuk alat, tanah dan bangunan. Sehingga dengan penambahan bahan baku untuk diolah, akan meningkatkan jumlah tenaga kerja.

\section{Pengaruh Variabel Nilai Penjualan Terhadap Penyerapan Tenaga Kerja pada Usaha Roti di Kota Payakumbuh}

Volume penjualan atau nilai penjualan dapat diartikan sebagai umpan balik dari kegiatan pemasarana yang dilakukan perusahaan dan dapat diukur dengan volume fisik atau volume rupiah. Hasil analisis menunjukkan bahwa nilai penjualan berpengaruh signifikan terhadap penyerapan tenaga kerja pada usaha roti di Kota Payakumbuh. Saat ini faktor utama yang mempengaruhi meningkatnya nilai penjualan yaitu permintaan pasar akan produk. Demi memenuhi permintaan konsumen maka usaha roti akan menambah tenaga kerja. Namun untuk kondisi saat penelitian di usaha roti belum melakukan penambahan tenaga kerja dikarenakan jumlah produksi per hari rata-rata tetap sehingga tenaga kerja yang digunakan masih sama belum ada penambahan. Penambahan tenaga kerja akan terjadi jika jumlah produksi bertambah atau lebih besar dari produksi rata-rata per hari dan tenaga kerja yang ada tidak mampu menyelesaikan proses produksi. Hasil penelitian sejalan dengan penelitian yang dilakukan (Umniati \& Arief, 2019) pada usah makanan dan minuman yang mengatakan bahwa nilai penjualan berpengaruh negatif terhadap peyerapan tenaga kerja dimana arah koefisien regresi yang negatif menunjukan bahwa peningkatan nilai penjualan dapat mengurangi penyerapan tenaga kerja.

Pengaruh Variabel Tingkat Produktivitas Tenaga Kerja Terhadap Penyerapan Tenaga Kerja pada Usaha Roti di Kota Payakumbuh

Produktivitas tenaga kerja merupakan tingkat kemampuan tenaga kerja dalam menghasilkan produk. Produktivitas tenaga kerja menunjukkan adanya kaitan antara output (hasil kerja) dengan waktu yang dibutuhkan untuk menghasilkan produk seorang 
tenaga kerja, jumlah produksi yang dapat dihasilkan oleh satu orang tenaga kerja dalam jangka waktu satu bulan. Perhitungan produktivitas tenaga kerja menggunakan rumus total jumlah produksi roti dalam satu bulan dibagi dengan input tenaga kerja produksi.

Hasil analisis menunjukkan bahwa produktivitas tenaga kerja berpengaruh tidak signifikan terhadap penyerapan tenaga kerja pada usaha roti di Kota Payakumbuh. Saat ini industri roti akan menambah tenaga kerja apabila jumlah produksi meningkat. Hal ini disebabkan karena jumlah tenaga kerja yang tersesdia memiliki keterbatasan dalam memproduksi roti. Penambahan tenaga kerja dilakukan untuk membantu tenaga kerja memproduksi roti. Namun untuk saat ini tenaga kerja yang digunakan masih mampu melaksanakan produksi roti. Hal ini disebabkan karena produksi roti yang tidak meningkat sehingga tenaga kerja yang digunkan masih mampu dalam memproduksi roti. Hal ini dibuktikan dengan $53 \%$ produktivitas per satu orang tenaga kerja pada usaha roti diatas rata-rata. Rata-rata produktivitas satu orang tenaga kerja pada usaha roti di Kota Payakumbuh yaitu $77 \mathrm{~kg} /$ orang. Hasil penelitian sejalan dengan penelitian yang dilakukan (Nurmaini, 2016), yang mengatakan bahwa produktivitas tenaga kerja berpengaruh negatif terhadap peyerapan tenaga kerja dimana arah koefisien regresi yang negatif menunjukan bahwa peningkatan produktivitas tenaga kerja dapat mengurangi penyerapan tenaga kerja.

\section{Pengaruh Tingkat Pendidikan Tenaga Kerja Terhadap Penyerapan Tenaga Kerja pada Usaha Roti di Kota Payakumbuh}

Hasil penelitian diperoleh informasi bahwa variabel tingkat pendidikan tenaga kerja mempunyai pengaruh yang signifikan terhadap penyerapan tenaga kerja pada usaha roti di Kota Payakumbuh, dengan adanya peningkatan pada tingkat pendidikan, maka akan diikuti pula oleh peningkatan produktivitas tenaga kerja secara signifikan sehingga menjadikan sebuah keuntungan bagi perusahaan. Menurut (Atiyatna et al., 2016) pendidikan juga mampu meningkatkan kemampuan dan daya saing seseorang, sehingga mampu meningkatkan bargaining position individu tersebut dalam pasar tenaga kerja, dan pada akhirnya memungkinkan individu untuk mendapat pekerjaan yang lebih baik.Pada penelitian ini perhitungan tingkat pendidikan tenaga kerja menggunakan asumsi perkalian yaitu menghitung total sekala perkalain pada setiap tingkat pendidikan tenaga kerja yang bekerja di rumah usaha tersebut (SD x1, SLTP x2, SMA x3 dan Sarjana $x 4$ ). Satuan tingkat pendidikan yang digunakan yaitu (orang). Berdasarkan

Hasil penelitian menunjukkan bahwa tingkat pendidikan tenaga kerja berpengaruh secara signifikan terhadap penyerapan tenaga kerja pada usaha roti di Kota Payakumbuh. Kondisi industri roti di Kota Payakumbuh menggambarkan semakin tinggi tingkat pendidikan tenaga kerja, maka tenaga kerja terseut akan diposisikan pada pekerjaan yang berbeda di bandingkan dengan tenaga kerja berstatus pendidikan lebih rendah, selain itu jumlah upa tenaga kerja yang diberikan oleh perusahaan lebih besar kepada tenaga kerja yang memiliki tingkat pendidikan lebih tinggi dibandingkan dengan tenaga kerja yang memiliki status pendidikan lebih rendah. Penelitian yang dilakukan Ganie (2017) pada penyerapan tenaga kerja di Kabupaten Berau Kalimantan Timur mengatakan bahwa tingkat pendidikan berpengaruh signifikan terhadap penyerapan tenaga kerja. 
Hal ini dapat dikaitkan dengan hasil temuan (Irwan et al., 2019) menyatakan bahwa karakteristik pendidikan memiliki keterkaitan dengan sektor pekerjaan dan arah lapangan usaha para pekerja. Hasil penelitian (Arnayulis et al., 2020) dapat dilihat bahwa tingkat pendidikan terhadap tingkat pendapatan individu, pekerja dengan pendidikan yang lebih rendah mempunyai pendapatan yang lebih rendah dibandingkan pekerja yang mempunyai tingkat pendidikan yang lebih tinggi. Hal ini terlihat dimana pekerja dengan tingkatan pendidikan minimal SLTP mempunyai resiko atau peluang yang lebih besar berpendapatan di bawah Rp400.000.

\section{Kesimpulan}

Faktor-faktor yang berpengaruh signifikan terhadap penyerapan tenaga kerja pada UMKM industri roti di Kota Payakumbuh yaitu variabel upah, nilai penjualan dan tingkat pendidikan tenaga kerja. Sedangkan variabel modal dan tingkat produktifitas tenaga kerja berpengaruh tidak signifikan terhadap penyerapan tenaga kerja pada UMKM industri roti di Kota Payakumbuh. Secara bersama-sama (simultan), variabel upah, modal kerja, nilai penjualan, produktivitas tenaga kerja, tingkat pendidikan tenaga kerja mampu menjelaskan sebesar $94,5 \%$ variasi penyerapan tenaga kerja. Sedangkan sisanya, 5,5\% penyerapan tenaga kerja dapat dijelaskan oleh variabel lain yang tidak digunakan dalam penelitian ini.

\section{Daftar Pustaka}

Anggrayini, N., Djumaty, B. L., \& Twofikasari, D. W. (2020). Analisis Penyerapan Tenaga Kerja Pada Usaha Mikro Kecil dan Menengah (UMKM) Kerupuk Amplang di Kecamatan Kumai, Kabupaten Kotawaringin Barat. Magenta, 9(1), 23-30.

Arnayulis, A., Afriza, R., \& Ashari, T. M. (2020). Seminar Nasional Virtual"Sistem Pertanian Terpadu dalam Pemberdayaan Petani". Pemetaan Tenaga Kerja Pada UMKM (Studi Kasus: Usaha Pengolahan Ubi Kayu Di Kota Payakumbuh), 316-325. http://repository.ppnp.ac.id/id/eprint/505

Atiyatna, D. P., Muhyiddin, N. T., \& Soebyakto, B. B. (2016). Pengaruh Upah Minimum, Pertumbuhan Ekonomi Dan Pendididikan Terhadap Penyerapan Tenaga Kerja Di Provinsi Sumatera Selatan. Jurnal Ekonomi Pembangunan, 14(1), 8-21. https://ejournal.unsri.ac.id/index.php/jep/index8

BPS Sumatera Barat. (2021). Sumatera Barat Dalam Angka. Sumatera Barat Dalam Angka 2021, 734. sumbar.bps.go.id

Handoko, M. (2016). Pengaruh Modal dan Upah Terhadap Penyerapan Tenaga Kerja pada UMKM di Kabupaten Bulungan (Studi Kasus: Kecamatan Tanjung Selor) [repository.ubt.ac.id]. https://repository.ubt.ac.id/index.php?p=show_detail\&id=4144\&keywords=

Hartono, D. (2021). Dampak Usaha Mikro Kecil Dan Menengah (UMKM) Terhadap Penyerapan Tenaga Kerja Pada Masa Pandemi Covid-19 Di Kabupaten Sumbawa. Journal Scientific of Mandalika (JSM), 2(12), 622-630. https://repository.ummat.ac.id/2920/

Irwan, H., Ayuningrum, F. T., Hutajulu, R. S., Nurhalimah, Rosiana, N., Rakhmawan, S. S., \& 
Indriyantika, D. F. (2019). Analisis Mobilitas Tenaga Kerja Hasil SAKERNAS 2020. In Analisis Mobilitas Tenaga Kerja Hasil Sakernas 2018.

Marti'ah, S. (2020). Penduduk, Angkatan Kerja, Penyerapan Tenaga Kerja pada Sektor Usaha Mikro Kecil dan Menengah (UMKM) di Jawa Barat. Jurnal Usaha, 1(2), 1-10.

Nugrahaeni, D. W., \& Handayani, H. R. (2020). Analisis pengaruh upah, modal, dan nilai produksi terhadap penyerapan tenaga kerja di industri tahu serasi kecamatan bandungan. Diponegoro Journal of Economics, 9, 56-65.

Nurmaini, M. (2016). Analisis Pengaruh produktivitas Tenaga Kerja, Upah Minimun dan Pertumbuhan Ekonomi terhadap Penyerapan Tenaga Kerja (Di 35 Kabupaten / Kota Provinsi Jawa Tengah Pada Tahun 2010-2014 ). Universitas Muhammadiyah Surakarta.

Nuryadi, Astuti, T. D., Utami, E. S., \& Budiantara. (2017). Dasar-Dasar Statistika Penelitian. http://lppm.mercubuana-yogya.ac.id/wp-content/uploads/2017/05/Buku-Ajar_Dasar-DasarStatistik-Penelitian.pdf

Rosyid, Z. (2017). Analisis Variabel-Variabel yang Mempengaruhi Penyerapan Tenaga Kerja pada UMKM Batik di Kota Surakarta (Studi Kasus pada Kampung Batik Laweyan dan Kampung Batik Kauman).

Samsu. (2017). Metode penelitian: Teori dan Aplikasi Penelitian Kualitatif, Kuantitatif, Mixed Methods, serta Research \& Development. In Pusat Studi Agama dan Kemasyarakatan (PUSAKA).

Saputri, P. A. (2021). Analisis Faktor-Faktor yang Mempengaruhi Eksistensi Industri Roti di Kota Padang. In Fakultas Pertanian, Universitas Andalas.

Syahrudin, M. F. R. (2017). Analisis Faktor-Faktor yang Mempengaruhi Penyerapan Tenaga Kerja UMKM Pada Sentra Industri Batik Tulis Klampar Kecamatan Proppo Kabupaten Pamekasan. Universitas Brawijaya.

Syuhada, S., Tasman, A., \& Hardiani. (2014). Faktor-faktor yang Mempengaruhi Penyerapan Tenaga Kerja pada Usaha Mikro, Kecil dan Menengah (UMKM) di Kota Jambi. Jurnal Perspektif Pembiayaan Dan Pembangunan Daerah, 2(2), 93-98.

Umniati, N., \& Arief, S. (2019). Analisis Faktor-Faktor yang Mempengaruhi Tingkat Penyerapan Tenaga Kerja pada Industri Makanan dan Minuman di Kota Surabaya. JEB: Jurnal Ekonomi \& Bisnis, 4(1), 819-834. 